\title{
SPALLATION THRESHOLD TESTS ON NIOBIUM, TANTALUM, AND ZIRCONIUM
}

G. P. HANNEMAN

SEPTEMBER 1968

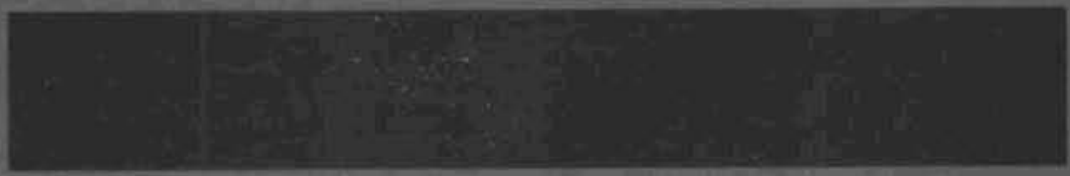

\section{AEC RESEARCH \& DEVELOPMENT REPORT}

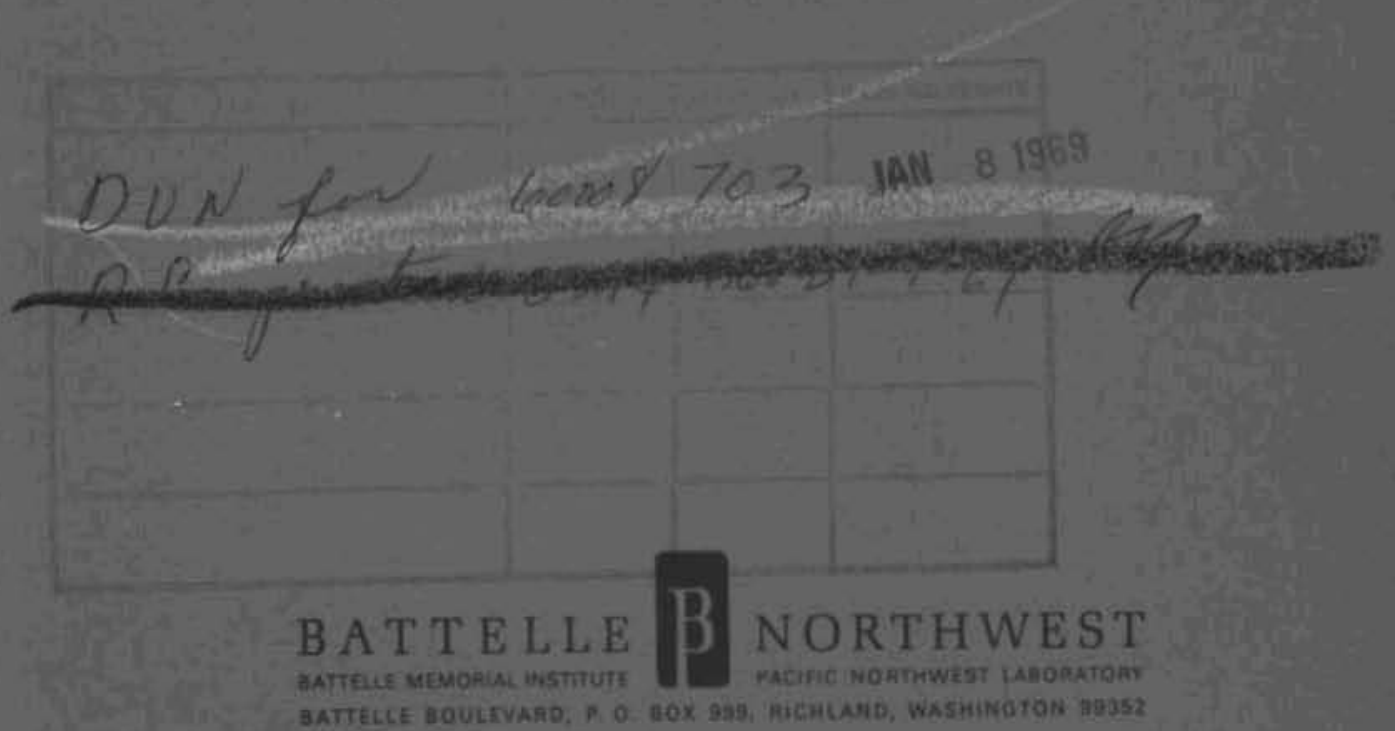




\section{LEGAL NOTICE}

This report was prepared as an account of Government sponsored work. Neither the United States, nor the Commission, nor any person acting on behalf of the Commission:

A. Makes any warranty or representation, expressed or implied, with respect to the accuracy, completeness, or usefulness of the information contained in this report, or that the use of any information, opparatus, method, or process disclosed in this report may not infringe privately owned rights; or

B. Assumes any liabilities with respect to the use of, or for damages resulting from the use of any information, apparatus, method, or process disclosed in this report.

As used in the above, "person acting on behalf of the Commission" includes any employee or contractor of the Commission, or employee of such contractor, to the extent that such employee or contractor of the Commission, or employee of such controcior prepares, disseminates, or provides access to, any information pursuant to his employment ar contract with the Commission, or his emplayment with such contractor.

\section{PACIFIC NORTHWEST LABORATORY RICHLAND, WASHINGTON \\ operated by}

BATTELLE MEMORIAL INSTITUTE

for the

UNITED STATES ATOMIC ENERGY COMMISSION UNDER CONTRACT AT(45-1)-1830 


\author{
BNWL - 756 \\ UC-25 Metals, \\ Ceramics, and Materials
}

\begin{abstract}
SPALLATION THRESHOLD TESTS
ON NIOBIUM, TANTALUM, AND ZIRCONIUM
\end{abstract}

By

G. P. Hanneman

Metallurgy Research Department

Chemistry and Metallurgy Division

September 1968

6

BATTELLE MEMORIAL INSTITUTE PACIFIC NORTHWEST LABORATORY RICHLAND, WASHINGTON 


\section{Printed in the United States of fmerica} Available from

Clearinghouse for Federal Scientific and iechnical Information National Bureali of Standards, U.S. Department of Commerce

Springfield, Virginia 22151

Price: printed Copy $\$ 3.00 ;$ Microfiche $\$ 0.65$ 


\section{SPALLATION THRESHOLD TESTS \\ ON NIOBIUM, TANTALUM, AND ZIRCONIUM}

G. P. Hanneman

\section{$\underline{\text { ABSTRACT }}$}

Niobium, tantalum, and zirconium specimens were heated to elevated temperatures in less than $8.0 \times 10^{-6} \mathrm{sec}$ by capacitor discharge. The ratio of heating time to thermal expansion time was maintained at unity or less to induce large tensile stresses. Single or multiple spallation was determined to occur in a plane normal to the long axis when temperature rose above a certain threshold. Spall threshold was found to be in the range of 1730 to $1860^{\circ} \mathrm{C}$ for niobium, 1900 to $2140{ }^{\circ} \mathrm{C}$ for tantalum, and 1150 to $1200{ }^{\circ} \mathrm{C}$ for zirconium. 


\section{TABLE OF CONTENTS}

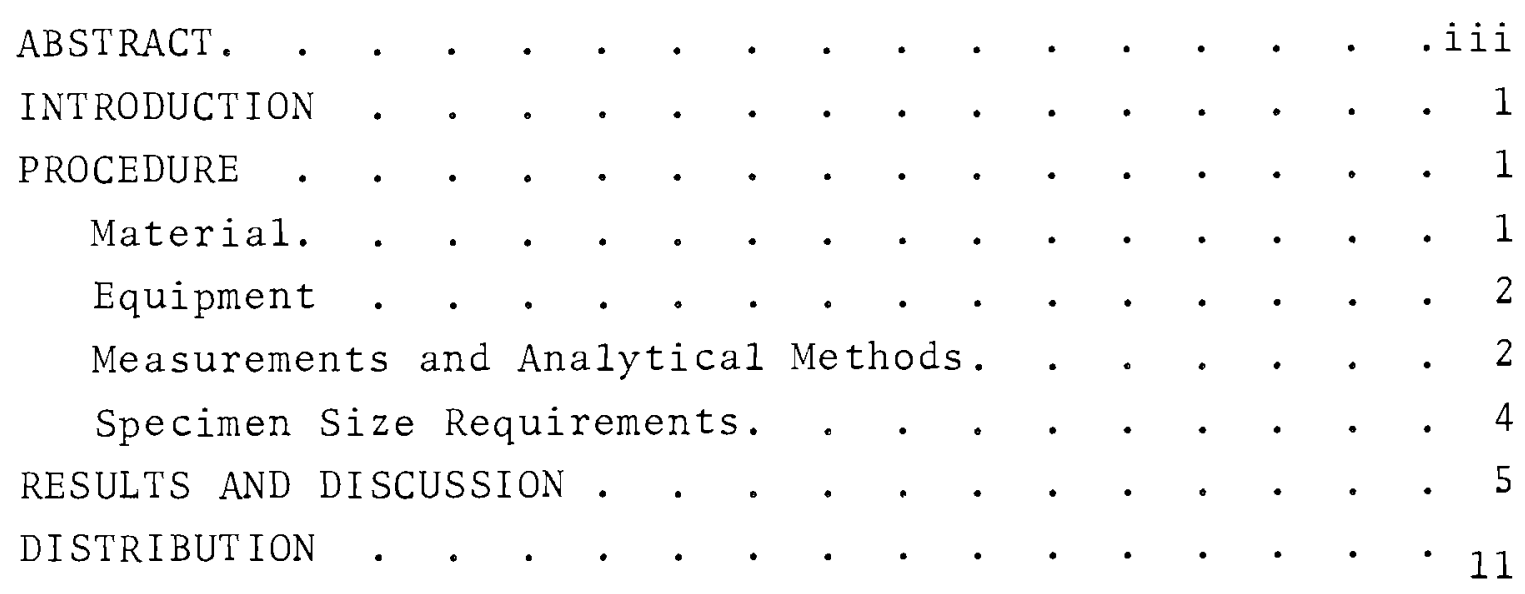




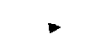

$\checkmark$

, 


\section{SPALLATION THRESHOLD TESTS \\ ON NIOBIUM, TANTALUM, AND ZIRCONIUM}

By

G. P. Hanneman

INTRODUCTION:

A spallation threshold study was performed on three refractory metals - niobium, tantalum, and zirconium. The approximate temperature above which each of these metals would fracture by spallation was determined.

When a narrow metallic strip or wire is uniformly heated so rapidly that the heating to expansion time ratio is equal to one or less, a significant compressive stress develops. The resulting rapid lengthwise expansion produces a tensile stress throughout the strip. If this stress is relatively low, the strip will simply cycle between compression and tension until the oscillation stops. At sufficiently high peak temperatures and tensile stresses, however, the strip will fracture or spall in a plane roughly perpendicular to its long axis.

\section{PROCEDURE}

\section{MATERIAL}

Two nominally pure niobium strips were obtained from cold-rolled 0.020 in. thick sheet by shearing and hand grinding to the final $0.020 \times 0.100 \times 2.00$ in. dimensions. Two nominally pure zirconium strips were similarly prepared from 0.030 in. thick sheet to $0.030 \times 0.100 \times 2.00$ in. dimensions. Six tantalum specimens were cut from annealed, $99.8 \%$ pure, $0.040 \mathrm{in}$. diam wire and ground to $2.00 \mathrm{in}$. length. 


\section{EQUIPMENT}

A diagram of the test equipment is illustrated in Figure 1. Energy for spallation was supplied from a bank of three high energy capacitors capable of storing up to $5600 \mathrm{~J}$ at 20,000 volts. Short, low-inductance buses led to the specimen mount in a nitrogen atmosphere, gloved box. Here the refractory metal specimens, mounted between the terminal ends of the buses, were contacted only through 0.001 in. diam copper wires at each end. A thin exploding wire switch, fitted into a thin slot all the way through one bus, was the mechanism used to start each test. During the first part of the capacitor discharge, of micro-sec duration, relatively low resistance contacting arcs were formed at the specimen ends by vaporization and ionization of the copper wire. Thus the specimen ends were free to thermally expand so that the spallation phenomenon could occur. This procedure permitted greater than $95 \%$ energy deposition in less than $8 \times 10^{-6}$ seconds.

\section{MEASUREMENTS AND ANALYTICAL METHODS}

Two test events were recorded. One was the differential output of a chromel/alumel thermocouple intrinsically buttwelded to the specimen. The other was the electronicallyintegrated output of a small inductive pickup coil located near one of the buses. The oscilloscope recording of a typical test shows representative current and thermocouple traces (Figure 2). The recording yields the total electrical resistance and inductance of the discharge circuit and, thus, the energy deposit with time. In addition, the peak temperature reached is also indicated. 


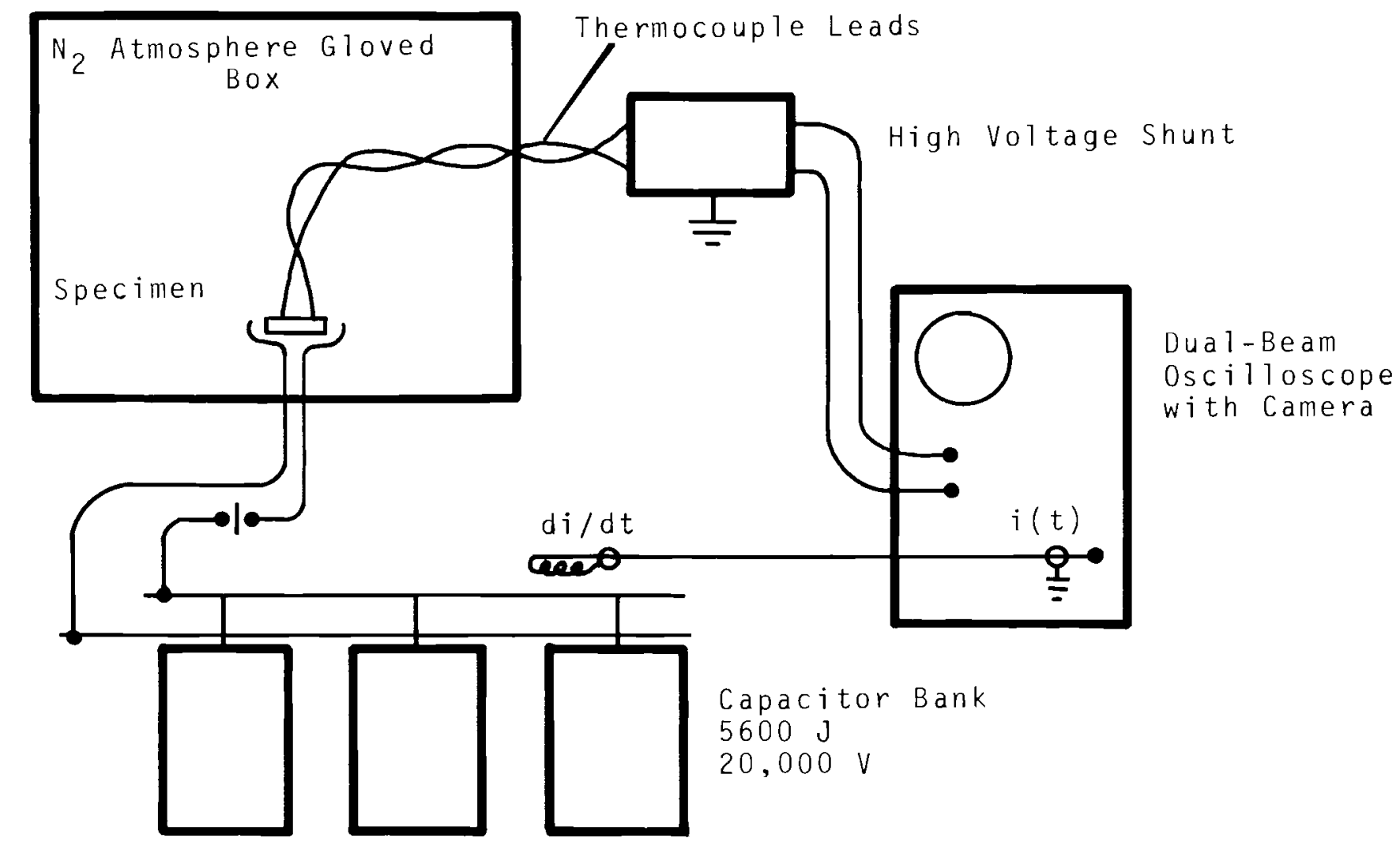

FIGURE 1. Diagram of Capacitor Discharge Test Equipment Used in Spazlation Threshold Studies 


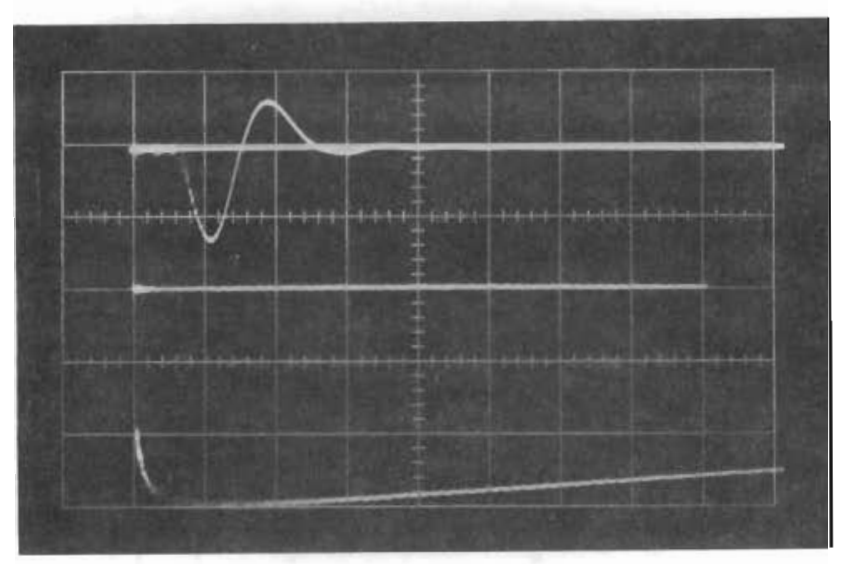

FIGURE 2. Typical oscizloscope Recording of the Dual-Beam Traces of Integrated Current and Thermocouple output. Upper Trace: $0.5 \mathrm{~V} / \mathrm{cm}$ at $5 x 10^{-6} \mathrm{sec} / \mathrm{cm}$. Lower Trace: $10 \mathrm{mV} / \mathrm{cm}$ at $0.1 \mathrm{sec} / \mathrm{cm}$.

The technique for determining the peak test temperature, attained when the the rmocouple failed, involved establishing a graphical relationship based on tests in which temperature measurement was obtained. The analytic form of the relationship is:

$\frac{\text { Total Stored Energy }}{\text { Specimen Mass }} \times \frac{\text { Avg Specimen Resistance }}{\text { Avg Total Circuit Resistance }}=$ Graphical Function of Temperature

This relationship resulted in an ordinary total heat input versus temperature curve. The Average Specimen Resistance term was evaluated at several points during heating because of variations, depending on the material and on the final temperature reached, of up to 5 times its starting value. SPECIMEN SIZE REQUIREMENTS

The surface heating effect was essentially eliminated in these tests by keeping the ratio, $\mathrm{R}_{\mathrm{HF}} / \mathrm{R}_{\mathrm{DC}}$, fairly close to 1.00. Here, $R_{H F}$ is the higher resistance of the specimen due to reduced current near the conductor center, a phenomenon of 
high frequency alternating current, while $\mathrm{R}_{\mathrm{DC}}$ is the direct current resistance. By using a standard graph relating this ratio to a function of current frequency, electrical resistivity, and conductor cross-section dimensions, a specimen cross section could be selected which would hold the ratio between 1.02 to 1.04 for a 11 three metals for tests over $1000^{\circ} \mathrm{C}$, where resistivities were relatively high.

A 2 in. specimen length was chosen for the three test materials to provide expansion time sufficient to achieve a $97 \%$ energy deposit for niobium, $99.5 \%$ for tantalum, and $99 \%$ for zirconium before any tensile stress could develop.

\section{RESULTS AND DISCUSSIDN}

The testing of niobium, tantalum, and zirconium over a wide range of temperatures below the spall threshold produced neasurable increases in cross section (Tables I, II, and III). This compressive plastic deformation indicated that the elastic limit was exceeded during the initial compressive loading. Plastic extension may have occurred during the tensile loading immediately following. However, measurements to determine the amount of this extension were not made. Sufficiently high stresses in the tensile cycle would result in spallation, frequently accompanied by necking.

As shown in Table I, Niobium Specimen No. 1 was tested seven times and No. 2 five times at successively higher temperatures until spallation occurred or testing was stopped (Figure 3). Although significant specimen thickening was found for tests at $1080{ }^{\circ} \mathrm{C}$ and above, test temperatures through $1730{ }^{\circ} \mathrm{C}$ did not cause spallation. The lowest temperature at which spall occurred was $1860^{\circ} \mathrm{C}$. Thus the spall threshold for niobium lay within the range 1730 to $1860{ }^{\circ} \mathrm{C}$. 
TABLEI. Physical Change in Niobium Strips as a Function of Sudden Temperature Rise from Room Temperature

\begin{tabular}{|c|c|c|c|c|}
\hline $\begin{array}{l}\text { Test } \\
\text { No. }\end{array}$ & $\begin{array}{l}\text { Deak } \\
\text { Temp, } \\
{ }^{\circ} \mathrm{C}\end{array}$ & $\begin{array}{c}\text { Initial } \\
\text { Condition } \\
\end{array}$ & $\begin{array}{c}\text { Cross-Section Change } \\
\text { from Prior Test, } \\
\frac{0}{0}\end{array}$ & Final Condition \\
\hline \multicolumn{5}{|c|}{ Specimen No. 1} \\
\hline$N 1-1$ & 420 & Cold-worked & +0.2 & No change observed \\
\hline N $1-2$ & 670 & Cold-worked & -0.5 & No change observed \\
\hline N1 $1-3$ & 930 & Cold-worked & +0.2 & No change observed \\
\hline$N 1-4$ & 1080 & Annealed* & +2.2 & $\begin{array}{l}\text { Thickened along } \\
\text { centerline while } \\
\text { strip narrowed }\end{array}$ \\
\hline N1 -5 & 1370 & Annealed* & +0.1 & $\begin{array}{l}\text { Thickened along } \\
\text { centerline while } \\
\text { strip narrowed }\end{array}$ \\
\hline N1 $1-6$ & 1720 & Annealed* & +4.2 & $\begin{array}{l}\text { Thickened along } \\
\text { centerline while } \\
\text { strip narrowed }\end{array}$ \\
\hline$N 1-7$ & 1860 & Annealed* & $(+12.5$ cumulative $)$ & $\begin{array}{l}\text { Thickened along } \\
\text { centerline while } \\
\text { strip narrowed } \\
\text { plus single break } \\
\text { near one end }\end{array}$ \\
\hline
\end{tabular}

Specimen No. 2

$\begin{array}{lrlll}\text { N5-1 } & 190 & \text { Cold-worked } & \text { ND** } & \text { No change observed } \\ \text { N5-2 } & 400 & \text { Cold-worked } & \text { ND** } & \text { No change observed } \\ \text { N5-3 } & 740 & \text { Cold-worked } & \text { ND** } & \text { No change observed } \\ \text { N5-4 } & 1190 & \text { Cold-worked } & \text { ND** } & \text { No change observed } \\ \text { N5-5 } & 1730 & \text { Annealed } & (+12.5 \text { cumulative }) & \begin{array}{l}\text { Finickened along } \\ \text { centerline while } \\ \end{array}\end{array}$

* Annealed by previous test
$*$ Denotes no data taken 
Separate tantalum specimens were used for each of the T1-1 to T1-5 tests (Table II and Figure 4), while one specimen was used in the T5-1 to T5-4 series. The highest test temperature reached without spall was $2140{ }^{\circ} \mathrm{C}$, while the lowest with spall was $1900^{\circ} \mathrm{C}$. Therefore, the tantalum spall threshold was placed between these two temperatures. TABLEII. Physical Changes in Tantalum wires as a Function of Sudden Temperature Rise from Room Temperature

\begin{tabular}{|c|c|c|c|c|}
\hline $\begin{array}{l}\text { Test } \\
\text { No. }\end{array}$ & $\begin{array}{l}\text { Peak } \\
\text { Temp, } \\
{ }^{\circ} \mathrm{C}\end{array}$ & $\begin{array}{c}\text { Initial } \\
\text { Condition } \\
\end{array}$ & $\begin{array}{c}\text { Cross-Section Change } \\
\text { from Prior Test, } \\
\frac{0}{0} \\
\end{array}$ & Final Condition \\
\hline $\mathrm{T} 1-2$ & 1890 & Annealed & +2.9 & No change observed \\
\hline $\mathrm{T} 1-4$ & 2140 & Annealed & $N D^{*}$ & Bent into curve \\
\hline $\mathrm{T} 1-5$ & 2200 & Annealed & $N D^{*}$ & Five breaks \\
\hline $\mathrm{T} 1-3$ & 2260 & Annealed & ND* & About nine breaks \\
\hline $\mathrm{T} 1-1$ & 3000 & Annealed & $N D^{*}$ & $\begin{array}{l}\text { Fine powder from } \\
\text { complete me1ting } \\
\text { and scattering }\end{array}$ \\
\hline$\Gamma 5-1$ & 390 & Annealed & $\mathrm{ND}^{*}$ & No change observed \\
\hline $\mathrm{T} 5-2$ & 840 & Annealed & $\mathrm{ND}^{*}$ & No change observed \\
\hline $\mathrm{T} 5-3$ & 1380 & Annealed & $N D^{*}$ & No change observed \\
\hline T $5-4$ & 1900 & Annealed & $N D^{*}$ & $\begin{array}{l}\text { Single break near } \\
\text { one end }\end{array}$ \\
\hline
\end{tabular}

* Denotes no data taken

As shown in Table III and Figure 5, Zirconium specimen No. 3 was tested eight times and No. 4 six times at successively higher temperatures until fracture occurred. The specimens remained intact up to $1150^{\circ} \mathrm{C}$, while fracture occurred at $\simeq 1200{ }^{\circ} \mathrm{C}$, indicating the zirconium spall threshold to be between 1150 to $1200{ }^{\circ} \mathrm{C}$. 
TABLE III. Physical Changes in Zirconium Strips as a Function of Sudden Temperature Rise from Room Temperature

\begin{tabular}{|c|c|c|c|c|}
\hline $\begin{array}{l}\text { Test } \\
\text { No. } \\
\end{array}$ & $\begin{array}{l}\text { Peak } \\
\text { Temp, } \\
{ }^{\circ} \mathrm{C} \\
\end{array}$ & $\begin{array}{l}\text { Initial } \\
\text { Condition }\end{array}$ & $\begin{array}{c}\text { Cross-Section Change } \\
\text { from Prior Test, } \\
\frac{0}{0} \\
\end{array}$ & Final Condition \\
\hline \multicolumn{5}{|c|}{ Specimen No. 3} \\
\hline $21-1$ & 590 & Cold-worked & +0.8 & Still intact \\
\hline $21-3$ & 740 & Cold-worked & $-0-$ & Still intact \\
\hline $21-4$ & 860 & Annealed* & +0.1 & Still intact \\
\hline $21-5$ & 920 & Annealed* & -0.4 & Still intact \\
\hline $21-6$ & 980 & Annealed* & +0.1 & Still intact \\
\hline $21-7$ & 1150 & Annealed* & $N D^{* *}$ & Still intact \\
\hline $21-8$ & $\simeq 1200$ & Annealed* & $\mathrm{ND} * *$ & $\begin{array}{l}\text { Broken off } \\
-0.1 \text { in. from } \\
\text { end plus other } \\
\text { end (-0.1 in.) } \\
\text { completely melte }\end{array}$ \\
\hline
\end{tabular}

Specimen No. 4

\begin{tabular}{|c|c|c|c|c|}
\hline $25-1$ & 220 & Cold-worked & $N D^{* *}$ & Still intact \\
\hline $25-2$ & 230 & Cold-worked & $\mathrm{ND}^{* *}$ & Still intact \\
\hline $25-3$ & 475 & Cold-worked & $N D^{* *}$ & Still intact \\
\hline $25-4$ & 750 & Co1d-worked & $N D * *$ & Stil1 intact \\
\hline $25-5$ & 1140 & Annealed* & $N D^{* *}$ & Still intact \\
\hline $25-6$ & 1300 & Annealed* & $N D^{* *}$ & $\begin{array}{l}\text { Two ragged breaks-- } \\
\text { one very near } \\
\text { center, other } \\
\simeq 0.1 \text { in. from end }\end{array}$ \\
\hline
\end{tabular}

* Anneared by previous test
* Denotes no data taken 
Temperature of Final Test

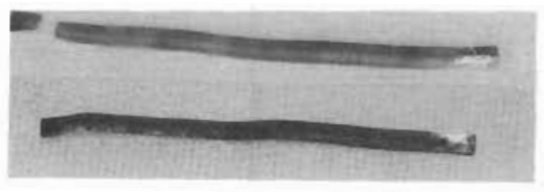

$1860{ }^{\circ} \mathrm{C}$

1730

FIGURE 3. Niobium Strips Tested for spallation Threshold, $\simeq 1 X$

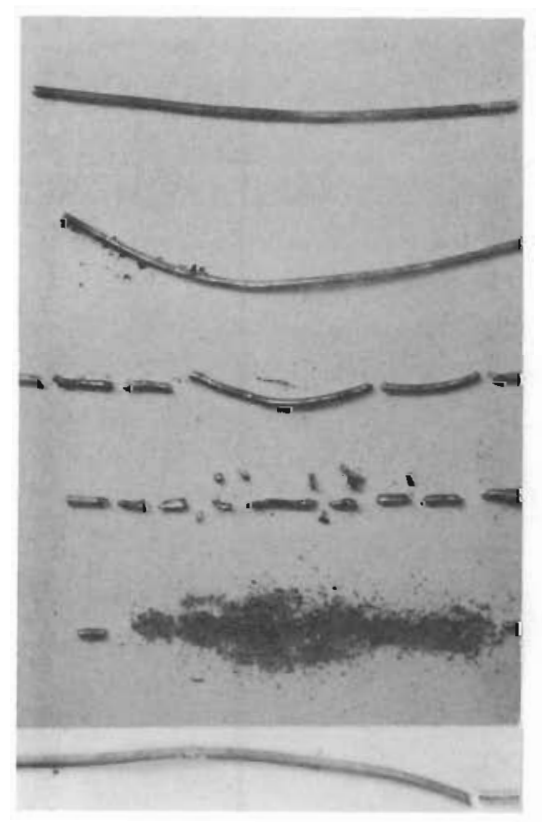

\section{Temperature of Final Test}

$1890{ }^{\circ} \mathrm{C}$

2140

2200

2260

3000

1900

FIGURE 4. Tantalum Wires Tested for spallation Threshold, $\simeq 1 X$

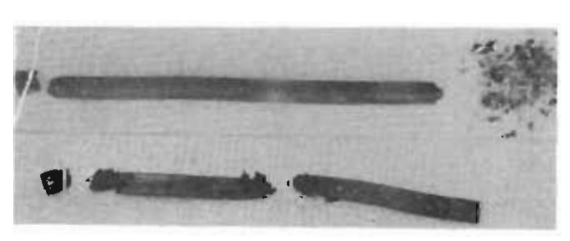

Temperature of Final Test

$$
\simeq 1200^{\circ} \mathrm{C}
$$

\section{0}

EIGURE 5. Zirconium Strips Tested for Spallation Threshold, $\simeq 1 X$ 


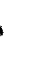




\section{DISTRIBUTION}

No. of

Copies

OFFSITE

1

AEC Albuquerque Operations Office

D. Johnston

Col. D. Overton

1

260

1

1

6

5

1

AEC Chicago Patent Group

G. H. Lee

AEC Library, Washington

Col. Z. Hagedorn

Div. Military Application

AEC Richland Operations Office

C. L. Robinson/J. L. Rhoades

AEC Rocky Flats Area Office

S. R. Woodruff, Jr.

Dow Chemica1 Company (AEC)

R. D. Forest

B. L. Kelchner

L. A. Matheson

J. E. Pavlick

L. W. Pribila

T. Vanvorous

Los Alamos Scientific Laboratory

R. M. Alire (Group W7)

R. D. Baker

L. Horpedah 1

W. J. Maraman

F. W. Schonfeld

1 Lawrence Radiation Laboratory, Berkeley

AEC Division of Technical Information Extension R. P. Conne 11 
No. of

Copies

21

Lawrence Radiation Laboratory, Livermore

C. T. Brockett

J. P. Diacanoff

F. S. Eby

E. H. Fleming

J. Hadley

C. R. Henry

J. O. Jepson (3)

W. M. Miller/D. E. Loewe

D. C. Oakley

H. N. Per 1

T. Perlman

W. J. Ramsey (6)

J. L. Robbins

R. G. Stone

ONS I TE-HAN FORD

1

3

37
AEC Chicago Patent Group

R. K. Sharp (Richland)

Battelle Memorial Institute

Batte11e-Northwest

V. C. Asmund

R. A. Busch

G. M. Dalen

S. D. Dahlgren

D. R. de Halas

R. E. Falkoski

H. R. Gardner

E. N. Greenwe 11

G. P. Hanneman

W. S. Hartnett

D. D. Hays

Y. B. Katayama

R. R. King, Jr.

E. D. McClanahan

D. M. Miller

R. W. Moss

R. D. Nelson

R. W. Stewart

J. M. Taylor

W. B. Weihermiller

O. J. Wick

- Technical Information

Technical Publications 